\title{
HE-MAN AND THE MASTERS OF THE UNIVERSE A TECNOCULTURA DOS ANOS 80 E UMA DAS PRIMEIRAS RECRIAÇÕES DO PÓS-HUMANO
}

\author{
HE-MAN AND THE MASTERS OF THE UNIVERSE \\ THE 80'S TECHNOCULTURE AND ONE OF THE FIRST \\ RECREATIONS OF THE POSTHUMAN
}

JOÃO JERÓNIMO MACHADINHA MAIA*

joamaia@hotmail.com

Este artigo tem como objetivo fazer uma revisitação do franchising He-man and the Masters of the Universe, um universo recreativo que se estendeu a várias áreas de negócio. Tratando-se de um universo concebido no contexto da tecnocultura dos anos 80 , recebeu a influência de vários elementos culturais e ideológicos que justificam a sua classificação como representação do póshumano. Inclusivamente, as representações de He-man em décadas posteriores não deixaram de revelar elementos interessantes para o estudo académico das recriações do pós-humano face aos desenvolvimentos ocorridos na cultura popular e na cultura de massas através dos média. No entanto, trata-se de um produto de entretenimento que continua a ser essencialmente dirigido ao público de fãs dos anos 80 , daí verificar-se determinadas particularidades na evolução das suas estórias.

Palavras-chaves: tecnocultura; anos 80; He-man; recriação; pós-humano.

This article aims to revisit the He-man and the Masters of the Universe franchise, a recreational universe that has extended to various business areas. As it was a universe conceived in the context of the technoculture of the 1980s, it received the influence of several cultural and ideological elements that justify its classification as a representation of the posthuman. In fact, He-man's representations in later decades did not fail to reveal interesting elements for the academic study of the posthuman recreations in the face of the developments that have occurred in the popular culture and in the mass culture through the media. However, it is an entertainment product that continues to be essentially aimed at the audience of fans of the 80 's, hence the existence of certain particularities in the evolution of their stories.

Keywords: technoculture; 80's; He-man; recreation; posthuman.

Data de receção: 2020-03-04

Data de aceitação: 2020-09-01

DOI: $\underline{10.21814 / 2 \mathrm{i} .2551}$

\footnotetext{
* Investigador Integrado, Universidade de Coimbra, Centro de Estudos Interdisciplinares do Século XX, Coimbra, Portugal, ORCID: 0000-0002-5392-9636
} 


\section{Introdução}

Na década de 80 do século XX, o desenvolvimento da revolução digital aliado a um novo modelo económico-social, tendo por base as políticas neoliberais, viriam a possibilitar a difusão à escala global da chamada tecnocultura refletindo as relações entre a tecnologia, a cultura e a política. A cultura pop, ou a cultura popular, não ficou imune a estas influências. Nos produtos para as crianças, ofranchising He-man and the Masters of the Universe foi uma das primeiras recriações do pós-humano no contexto da tecnocultura dos anos 80 fazendo uma síntese original de elementos tecnocientíficos com elementos medievalísticos e com elementos mitológicos, o que lhe granjeou grande sucesso em diversas partes do mundo (Selley \& Selley, 2015). Nesta medida, o franchising, pelo menos no seu formato original, não deixou de evidenciar uma certa fusão e até tensão entre elementos tradicionais e elementos da modernidade.

Neste artigo, iremos revisitar o universo de He-man and the Masters of the Universe e de um spin-off dele derivado, She-ra: Princess of Power, nos formatos originais dos anos 80 e nas recriações que surgiram nas décadas seguintes. Serão apresentadas e debatidas as influências culturais e ideológicas que marcaram estes universos e que justificam a sua classificação como representações do pós-humano. A integração dos elementos tecnológicos nestes universos de recriação obedece ao quadro político e cultural próprio dos anos 80 ao mesmo tempo que também aparecem refletidos aspetos do pensamento feminista e ecologista que se desenvolvia na altura. Aliás, a diversidade de elementos nas representações tanto de He-man como de She-ra enquadram-se num sistema de franchising na comercialização dos seus produtos onde a lógica de negócio e de procura de lucro prevalece sobre os aspetos criativos. Este facto, para além do ambiente social e cultural dos anos 80 e das décadas subsequentes, é decisivo para as conclusões a tirar sobre a caraterização e a evolução de ambos os universos ao longo dos anos.

\section{O lançamento do franchising}

Em 1982, a empresa multinacional norte-americana Mattel lançou a linha de brinquedos, action figures, He-man and the Masters of the Universe. Depressa se desenvolveu um franchising que se estendeu no mesmo ano à banda desenhada, no ano seguinte aos desenhos animados com a empresa Filmation e no ano de 1987 ao cinema, para além, inclusivamente, de outros produtos de entretenimento como videojogos, calendários de bolso e cadernetas de cromos (Selley \& Selley, 2015). Mais do que um produto para crianças assente na visão maniqueísta da luta entre o Bem e o Mal, combinando elementos da tecnociência com elementos da mitologia, o universo He-man representa uma das primeiras recriações do pós-humano no contexto da tecnocultura dos anos 80 através da cultura pop. 


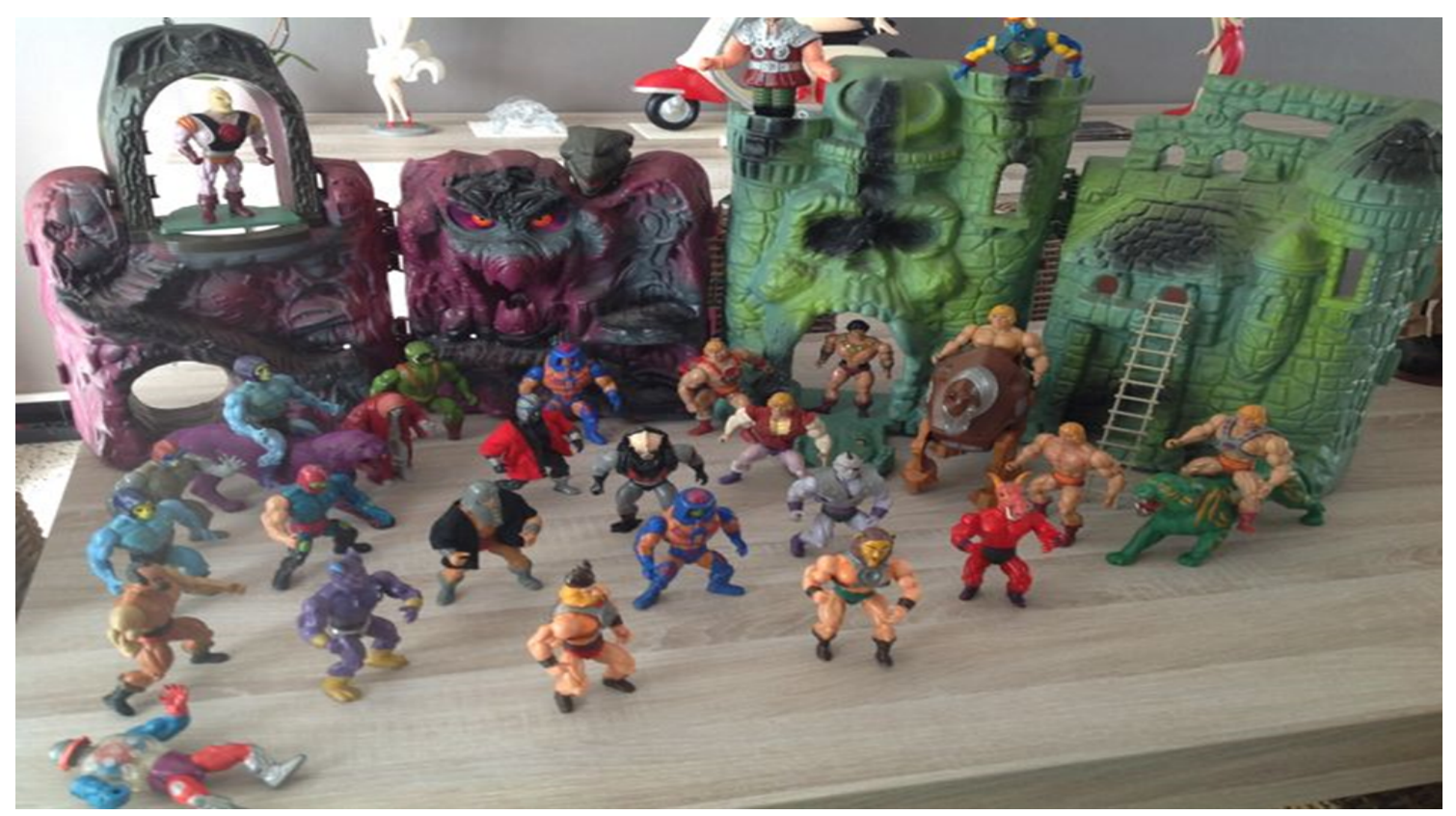

Fig.1. Linha de action figures, He-man and the Masters of the Universe.

Na narrativa dos Masters of the Universe (MOTU), o centro do poder do universo é o Castelo de Grayskull que tem como guardiã a Feiticeira. O personagem Príncipe Adam (em português, Príncipe Adão), o primeiro homem, recebe o poder do Castelo de Grayskull através da espada do poder permitindo-lhe realizar a transformação no seu alter-ego, a personagem principal da narrativa, He-man (em português, Ele-homem), o homem mais poderoso do universo, que tem na Feiticeira de Grayskull a sua guia espiritual. Neste quadro, tanto nos cenários da banda desenhada como nos cenários dos desenhados animados, podemos observar uma síntese original de elementos mitológicos, medievais e tecnocientíficos que fizeram do universo MOTU, durante a década de 80 , um franchising de grande sucesso em muitos países de diferentes partes do mundo (Selley \& Selley, 2015).

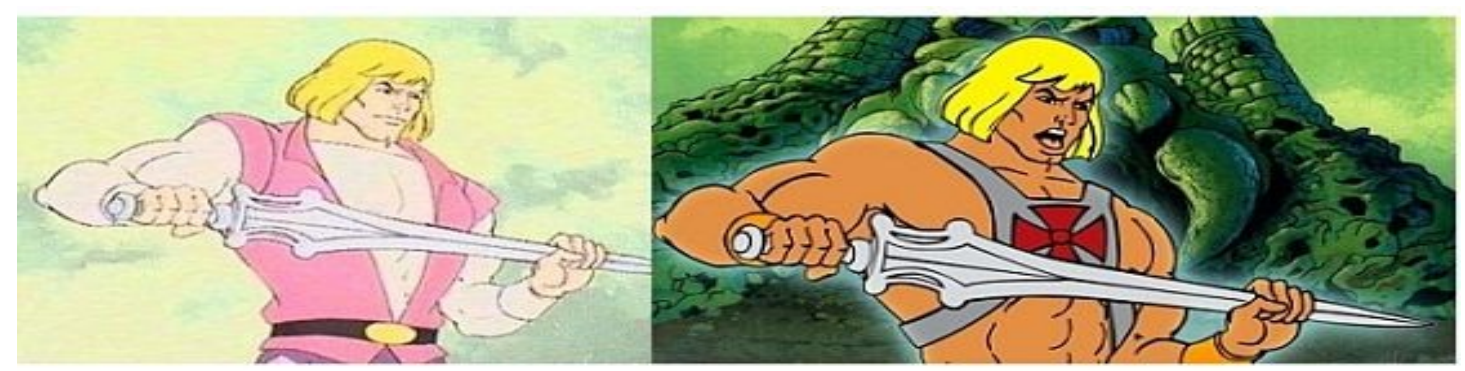

Fig.2. Transformação de Adam em He-man com o Castelo de Grayskull em fundo (desenhos animados). 

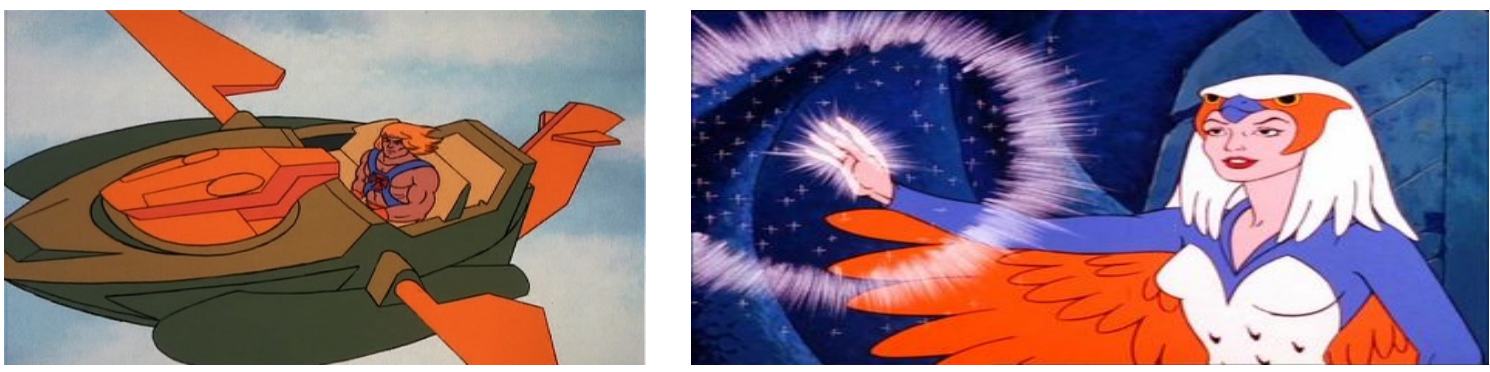

Fig.3. Veículo aéreo transportando He-man (des. ani.). Fig.4. Feiticeira, guardiã do Castelo de Grayskull (desenhos animados).

Concretamente, em baixo, como exemplos dos diferentes tipos de elementos referidos, na figura 5, podemos observar uma primeira tira de banda desenhada com cenas de ação em que intervém Zoar, um falcão armado com equipamento bélico, juntamente com Teela, fiel companheira de He-man na luta contra o Mal, vestida com o uniforme da antiga deusa Serpos. Na mesma figura pode-se verificar uma luta entre He-man e o seu arqui-inimigo e principal vilão, Skeletor. Numa segunda tira de banda desenhada (figura 6) é observável uma luta entre Fisto, caído no chão, e dois guerreiros do Mal, híbridos entre o humano e o animal. Na mesma cena também está presente um cavalo robótico, Stridor, o meio de locomoção de Fisto.

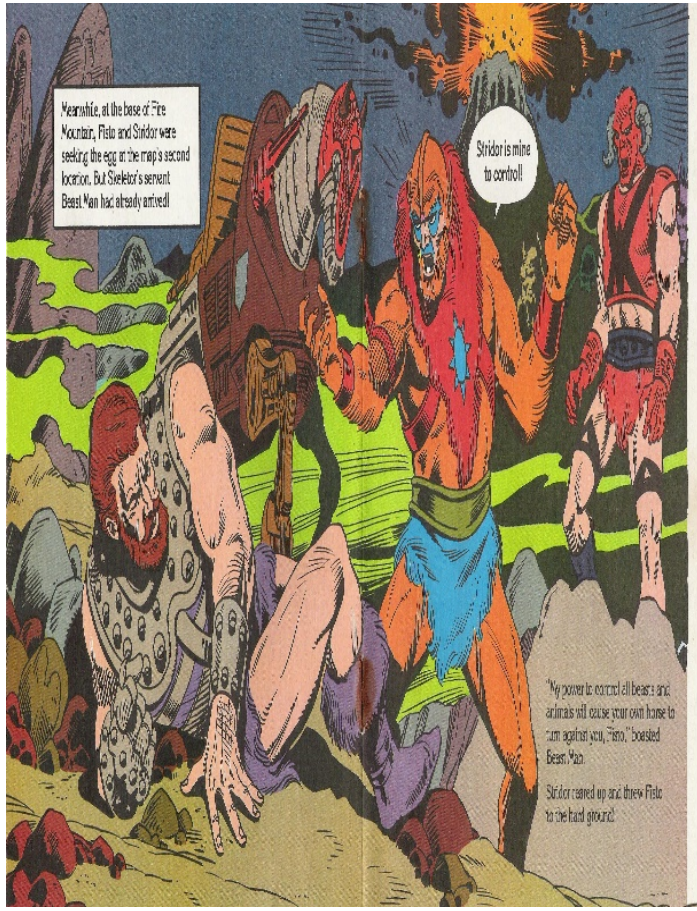

Fig.5. Primeira tira de banda desenhada MOTU.

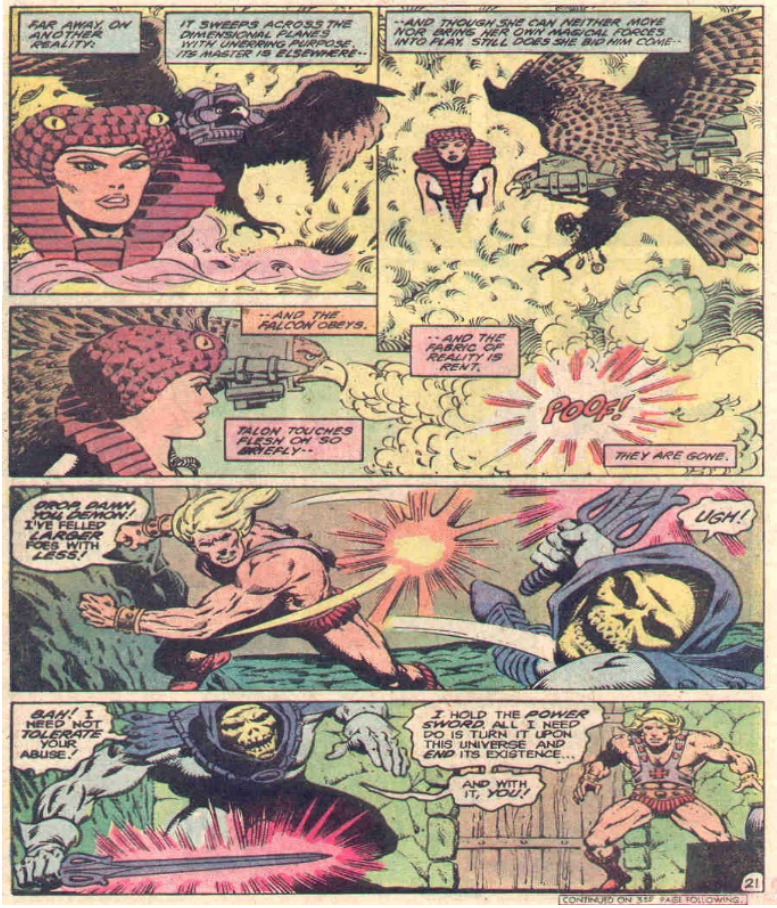

Fig.6. Segunda tira de banda desenhada MOTU.

\section{Os anos 80, a tecnocultura e a utopia do corpo}

Há que precisar que of franchising He-man and the Masters of the Universe foi criado e desenvolvido num contexto histórico muito particular. Em concreto, a década de 80 do século $\mathrm{XX}$, em que aconteceram transformações muito significativas a nível social, cultural, tecnológico e económico. Durantes estes anos consolidou-se a revolução digital com a generalização do computador pessoal (introduzido na década anterior), tanto no 
contexto privado como no contexto de trabalho, e com o desenvolvimento da internet, culminando com a criação da World Wide Web no final da década por Tim Berners-Lee. Os anos 80 também foram o berço do neoliberalismo com as políticas aplicadas nos Estados Unidos da América pela administração do presidente Ronald Reagan e com as políticas aplicadas no Reino Unido pelo governo da primeira-ministra Margaret Thatcher. Tanto o modelo económico-social neoliberal como a crescente digitalização da sociedade viriam a constituir de forma decisiva a configuração do atual modelo político-económico globalizado que se implementou no início da década de 90 do século passado, após a queda do bloco soviético (Maia, 2018).

José Bragança de Miranda (2002), um autor central na área da teoria da cultura em Portugal, tem uma visão crítica sobre os fenómenos associados à globalização neoliberal e à tecnocultura. Segundo ele, através dos meios tecnológicos dominantes propagam-se injustiças de todo o género legitimando, por exemplo, a dominação das grandes empresas e o intervencionismo militar. A tecnocultura, refletindo as relações entre a tecnologia, a cultura e a política, cria um mundo à imagem de determinados grupos e interesses dominantes. Para o autor, isto é feito através de imagens meios-fins onde tudo se torna em meio sem fim. A imagem não deixa de transmitir uma certa efemeridade do corpo e de todas as corporeidades. A modernidade cria automatismos que, por sua vez, levam a ruturas para agir livremente. O corpo é encarado como a derradeira utopia encarnada em conceitos de corpo supostamente bem trabalhado como os bodybuilders ou em conceitos de corpo que integram elementos tecnológicos ou futurísticos, como os ciborgues, híbridos entre o humano e a máquina. Estamos perante conceções de corpo que, no sentido empregue por José Bragança de Miranda, se relacionam com a funcionalidade e a eficiência exigidas pelo neoliberalismo. Daí o aparecimento de corpos musculados e/ou robotizados na cultura popular e na cultura de massas. Isto, aliás, reflete a perda da transcendência do impulso utópico, embora haja contaminação em zonas de fronteira da qual resultam estes conceitos híbridos. "Em suma, o corpo tornou-se urgente porque a sua crise implica uma crise de alcances metafísicos absolutos" (p.183). "O híbrido é, antes de mais, o efeito de uma 'confusão' de fronteiras e de linhas, que se sustentam do extremar da categoria de corpo. A utopia do 'corpo político' da comunidade perfeita, é suportada pelo 'corpo utópico' contemporâneo" (p.184). Na atualidade, o corpo torna-se o centro porque se identifica com o próprio mundo. Deste modo, o conceito do "corpo utópico" substitui a ideia da sociedade utópica ou da utopia social. Isto obedece a uma lógica de despolitização da sociedade em que já não se tenta mais pensar esta nos seus fundamentos nem se considera a possibilidade da sua evolução, quiçá, para uma comunidade. Neste contexto, a política está cada vez mais submetida à lógica da eficiência, sendo dada prioridade à economia sobre o humano, que, por sua vez, tende a ser formatado em termos do padrão de corpo. Os mecanismos de biopoder, segundo os quais estes processos ocorrem, encontram fundamento na obra de autores como Michel Foucault (1993), embora tenham uma tradução própria na forma como se materializam na especificidade do nosso tempo. São processos que ocorrem como extensão e transformação dos processos que tiveram origem na instituição da sociedade burguesa, adquirindo, por isso, manifestações distintas de acordo com a contemporaneidade.

\section{As figuras dos Masters of the Universe}

Tendo constituído uma das primeiras recriações do pós-humano pela tecnocultura dos anos 80, He-man and the Masters of the Universe refletiu em muitas das suas personagens determinados elementos culturais que proliferaram na cultura pop da época. Neste 
sentido, o franchising transpôs nos seus produtos os conceitos de corpo referidos anteriormente. Nas principais personagens do universo MOTU podemos observar exemplos do "corpo bem trabalhado" obedecendo, em vários casos, ao protótipo dos bodybuilders. Nas figuras 7, 8 e 9 estão representados, respetivamente, do lado dos guerreiros heroicos, He-man, Teela e Man-at-arms, pai adotivo de Teela e irmão de Fisto. Todos eles respeitam um padrão de corpo bem definido e, no caso dos homens, bastante musculado. Até mesmo Skeletor (figura 10), apesar de ser um guerreiro do Mal com uma face esquelética, apresenta à semelhança de He-man o mesmo padrão de corpo.

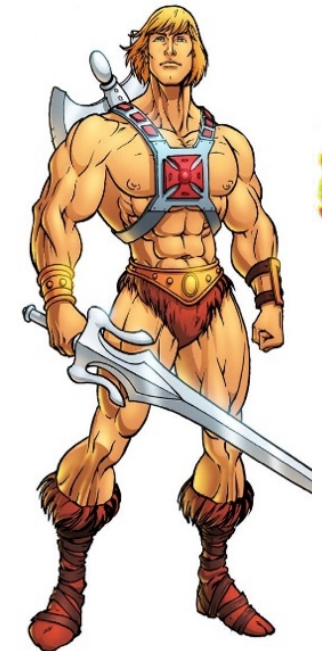

Fig.7. He-man (BD).

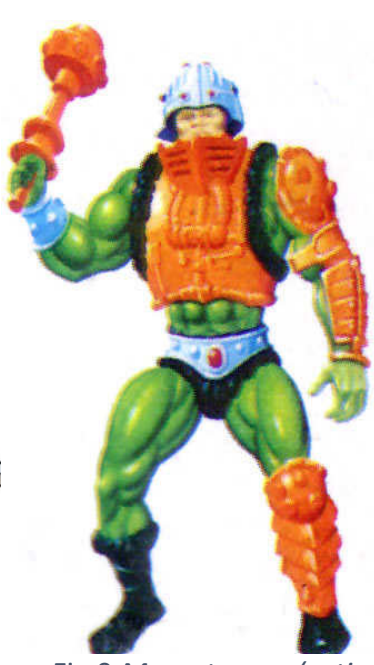

Fig.9.Man-at-arms (action figure).

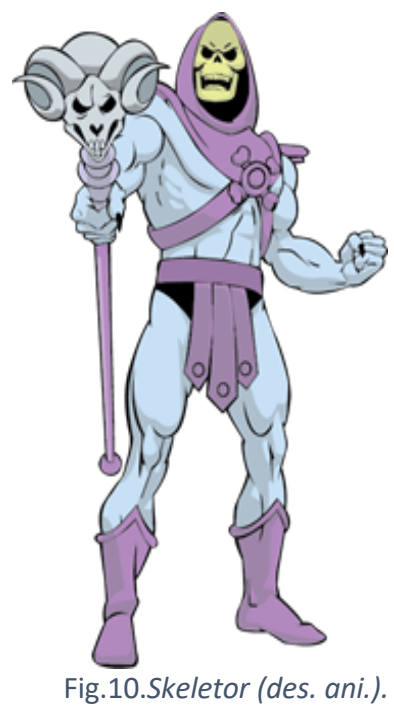

Fig.10.Skeletor (des. ani.).

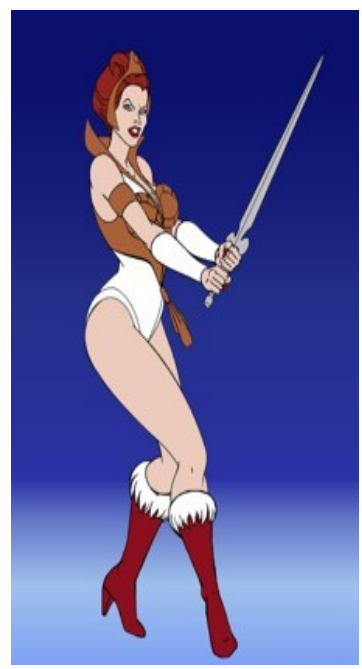

Fig.8.Teela (des. ani.)

Também a figura dos ciborgues é bastante comum no universo MOTU pela integração dos elementos tecnocientíficos nos cenários mitológicos e medievalísticos. As figuras que se seguem apresentam personagens deste universo cujos corpos são construídos, em parte, de forma artificial, correspondendo à definição típica do ciborgue, isto é, o híbrido entre o humano e a máquina. Como um primeiro exemplo, na figura 11, está representado o guerreiro heroico Sy-klone. Este personagem, tendo um corpo em grande parte mecânico, consegue girar sobre si próprio originando ventos ciclónicos com os quais combate os inimigos. A figura 12 volta a representar o guerreiro heroico Fisto, cuja mão, revelada como sendo cibernética em representações mais recentes, dá-lhe um grande poder de ataque em situações de luta corpo-a-corpo. A figura 13 representa um guerreiro do Mal: Trap Jaw. Este personagem tem boa parte do seu corpo reconstruído por próteses, incluindo o queixo e um dos membros superiores que funciona como arma que dispara feixes lasers contra os inimigos. Finalmente, a figura 14 volta a representar um guerreiro heroico: Extendar. Como ciborgue, este personagem consegue estender o seu tronco e os membros inferiores e superiores o que lhe permite adquirir vantagem sobre o inimigo em cenário de batalha. 


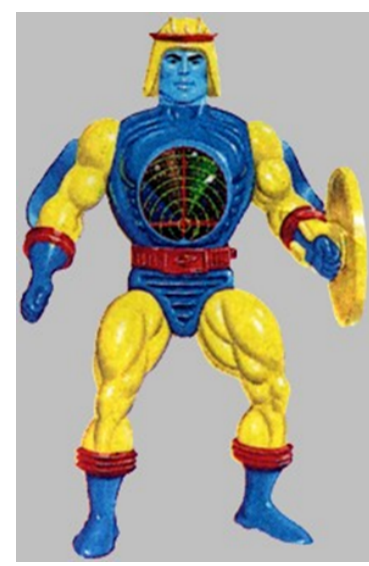

Fig.11.Sy-klone (action figure).

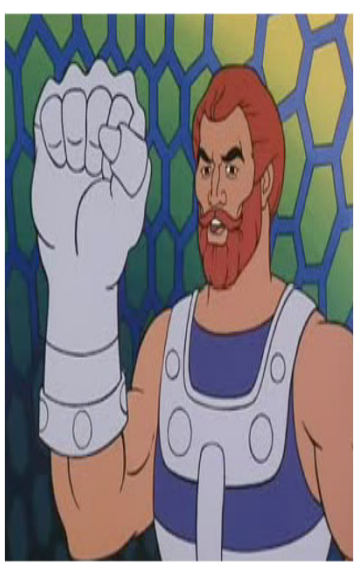

Fig.12.Fisto (des. ani.).

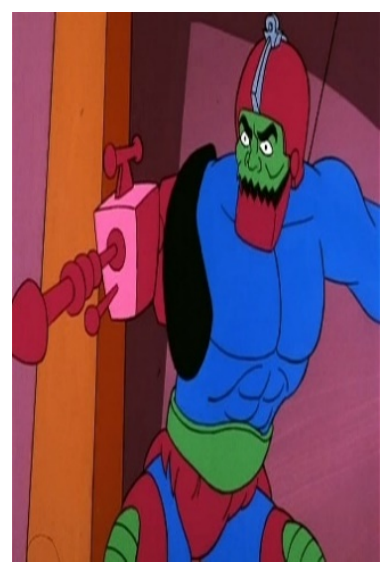

Fig.13.Trap Jaw (des. ani.).

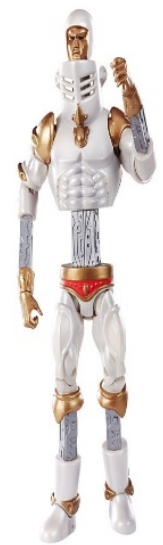

Fig.14.Extendar (action figure).

Para além do protótipo de corpo bodybuilder e do ciborgue, uma outra figura cuja representação é muito comum no universo MOTU é o híbrido homem-animal ou homembesta. Embora seja possível encontrar alguns exemplos de representações desta figura nos guerreiros heroicos, ela é mais comum nos guerreiros do Mal como se verifica nos exemplos em baixo ilustrados: Figura 15 - Kobra Khan: o híbrido entre o homem e a serpente; Fig. 16 - Beast Man ou o Homem-Besta; Fig.17 - Mer-man: o híbrido entre o homem e o peixe; Fig.18 - Mantenna, uma figura pertencente à chamada Horda do Mal sendo, por isso, uma personagem transversal tanto ao universo MOTU como a um spinoff referido mais à frente neste texto (Selley \& Selley, 2015).

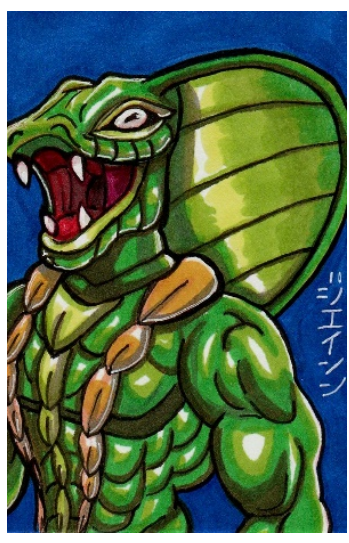

Fig.15.Kobra Khan (BD).

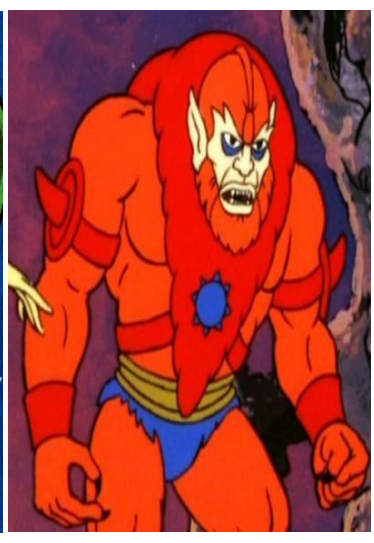

Fig.16.Beast Man (des. ani.).

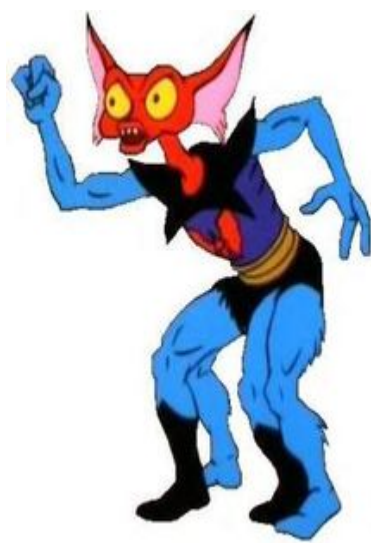

Fig.17.Mer-man (BD).

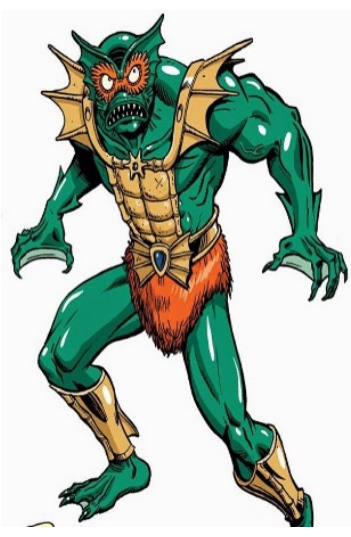

Fig.18.Mantenna (des. ani.).

A conjugação das representações destes três tipos de figuras, bodybuilder, ciborgue, homem-besta, no He-man and the Masters of the Universe, obedece muito a uma linha de pensamento da teoria pós-humana que debate e contrapõe de forma crítica as figuras da máquina, humano e animal desconstruindo os conceitos e até diluindo as fronteiras entre os mesmos. Desta forma, são colocadas em causa as nossas representações de humano, nomeadamente aquelas que, estando mais cristalizadas na cultura ocidental, marcam uma fratura ontológica entre o homem e outras entidades ou seres (Maia, 2017). Concretamente, a tradição teológica monoteísta, que é dominante na cultura ocidental, estabeleceu durante muito tempo, na nossa sociedade, uma visão cosmológica em que 
Deus é o responsável pela criação do mundo, dos animais e dos seres humanos. É uma visão que, à partida, não se compatibiliza com a tese darwinista da evolução gradual entre os animais e os seres humanos. Esta última visão também defende que o uso da tecnologia por parte da espécie humana, desde os seus primórdios, serviu para transformar o corpo humano (Darwin, 2009). Nesta medida, as figuras presentes, no franchising abordado, tendem a contrapor a tensão entre visões cosmológicas distintas, uma vez que representam figuras mitológicas como feiticeiras com poderes sobrenaturais ao mesmo tempo que apresentam ciborgues e homens-animais que diluem as fronteiras ontológicas estabelecidas na mitologia e na teologia ocidentais.

\section{O filme Masters of the Universe (1987)}

O universo MOTU chegou ao grande ecrã no ano de 1987 com um filme produzido pela Cannon Films, precisamente intitulado Masters of the Universe (Selley \& Selley, 2015). Este filme de Hollywood não foi na altura um grande sucesso nem de bilheteira nem para a crítica. O próprio realizador, Gary Goddard, assumiu que o orçamento disponível para a realização estava aquém da dimensão exigida para este universo ficcional. Tais limitações levaram a que grande parte da estória decorresse no planeta Terra. A certa altura, tanto os heróis como os vilões são transportados do seu planeta-mãe, Eternia, através da chamada chave-cósmica, para o planeta Terra, onde interagem com um casal de namorados daí natural (figura 22), interpretados pelos atores Courteney Cox e Robert Duncan McNeill. A interpretação de Skeletor (figura 20), por parte do ator Frank Langella, foi um dos poucos elementos elogiados pela crítica. No entanto, é um filme que teve o mérito de transportar para o cinema muitas das principais figuras do franchising: por exemplo, para além de Skeletor, na figura 19 temos no principal plano à esquerda Heman, interpretado pelo ator sueco Dolph Lundgren (o Ivan Drago de Rocky IV); ao centro Teela, interpretada pela atriz Chelsea Field; e à direita a Feiticeira, interpretada pela atriz Christina Pickles.

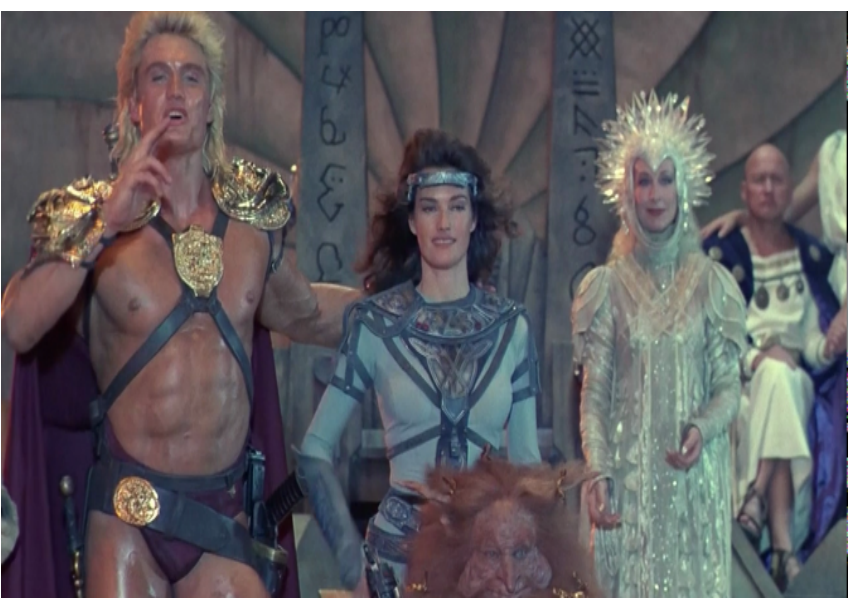

Fig.19. He-man, Tella e a Feiticeira.

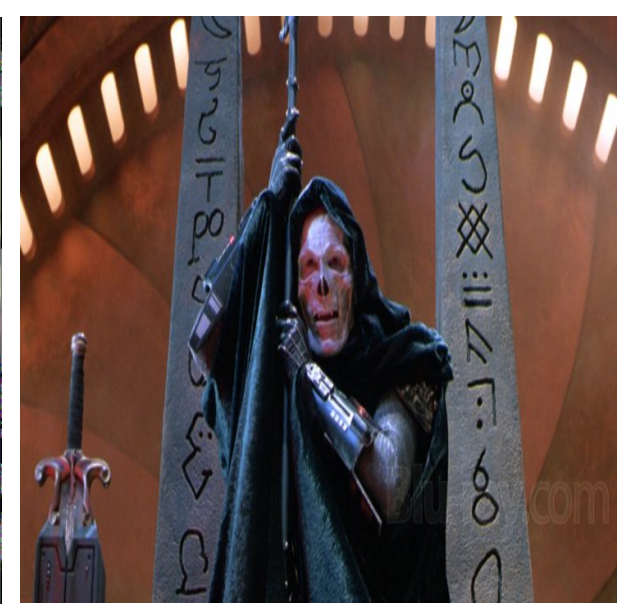

Fig.20. Skeletor

Na figura 21 estão em ação os guerreiros do mal, Saurod interpretado por Pons Maar, Beast Man interpretado por Tony Carroll, Karg interpretado por Robert Towers e Blade interpretado por Anthony De Longis. Tal como acontece nas representações dos desenhos animados e da banda desenhada, as figuras do homem-animal, representadas neste filme, incluem-se, na sua maioria, ou na quase totalidade, no grupo dos vilões, enquanto os 
guerreiros heroicos tendem a assumir formas humanas. Embora isto não seja uma exclusividade do universo MOTU, no que diz respeito à cultura de massas para públicos infantojuvenis, podemos questionar se não estará aqui implícita uma visão antropocêntrica que atribui a bondade, por um lado, às figuras inteiramente humanas, e atribui a maldade, por outro lado, aos híbridos do humano com a besta. Neste campo, o universo MOTU retratará mais fielmente a ideia de modernidade embora, como discutiremos mais à frente no artigo, isso não seja uma constante do franchising.

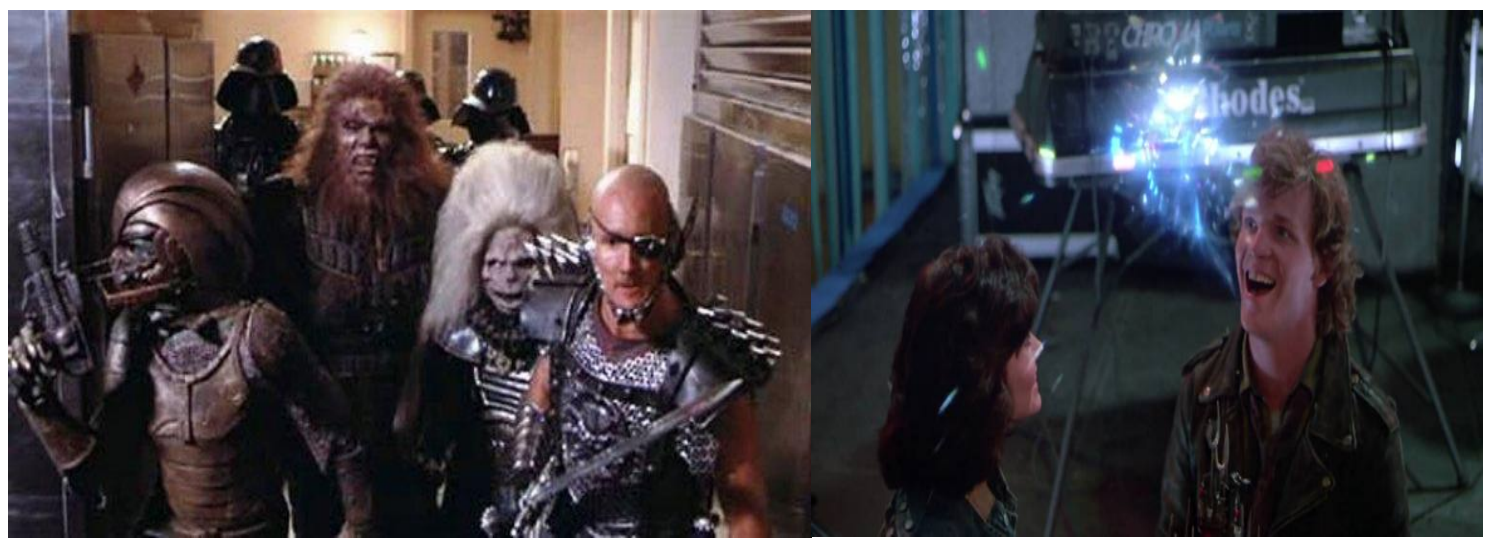

Fig.21.Vilões: Saurod, Beast Man, Karg e Blade

Fig.22. Casal de namorados olham o efeito da chavecósmica.

Apesar do falhanço comercial e crítico, o filme Masters of the Universe é hoje classificado como um filme de culto. Isto acontece porque muitos elementos da grande legião de fãs do franchising, nos anos 80 , ainda hoje recordam e comentam o filme em muitos círculos, nomeadamente on-line.

\section{Feminismo e ecologismo em She-ra: Princess of Power}

Como já foi referido, o franchising He-man and the Masters of the Universe foi criado e desenvolvido no contexto muito particular, a vários níveis, dos anos 80 . Foi por esta altura que conceitos como pós-humano e pós-humanismo começaram a ser estudados de forma mais sistemática nos meios académicos. Em especial, desenvolveu-se a corrente do póshumanismo crítico que teve como obra marcante o Manifesto Ciborgue da autora norteamericana Donna J. Haraway (1995). Esta obra embora tenha começado a ser escrita em 1983, só foi publicada em 1985 na revista britânica Socialist Review. Trata-se de um texto que faz a apologia da aplicação da tecnologia ao ser humano, em especial ao corpo humano, mediante a redefinição das relações de poder de modo a favorecer os equilíbrios sociais e ambientais. Nesta medida, trata-se também de um texto marcante numa linha de pensamento feminista e ecologista do pós-humanismo crítico, fazendo referência às relações humanas com animais e com figuras mitológicas. É notável a passagem da autora ao referir: "It means both building and destroying machines, identities, categories, relationships, space stories. Though both are bound in the spiral dance, I would rather be a cyborg than a goddess" (p.181). Trata-se de uma afirmação que se enquadra numa linha de pensamento pós-humano que admite o contributo da tecnologia para a emancipação feminina por oposição às figuras ancestrais e tradicionais que, por sua vez, podem ser vistas como fonte de reprodução da dominação da mulher.

Nesta linha de raciocínio, podemos evidenciar aqui mais um exemplo de como o pensamento e a atmosfera cultural dos anos 80 influenciaram o universo MOTU. São 
influências que não são estabelecidas necessariamente por uma linha de causa-efeito. Quando se criam ou quando se estabelecem determinado tipo de ideias numa sociedade, a cultura popular, e a arte, em geral, tendem a representar essas ideias mesmo que não o façam de uma forma coerente, ao misturá-las com ideias de correntes opostas que também estão presentes na sociedade da época. $\mathrm{Na}$ verdade, é o próprio ambiente sociocultural que determina estas representações que, por vezes, evidenciam as tensões e as contradições existentes do ponto de vista social. E, de facto, no mesmo ano de 1985, em que é publicado o Manifesto Ciborgue, a Filmation lança uma série de animação que é um spin-off de He-man and the Masters of the Universe. Trata-se de She-ra: Princess of Power, irmã gémea de He-man. Os próprios produtores desta série assumiram que queriam dar corpo a uma personagem que refletisse os ideias feministas e ecologistas (Selley \& Selley, 2015). Nesta medida, também se trata de um produto mais dirigido para um público consumidor feminino, ao contrário de He-man que era mais dirigido a um público consumidor masculino. Na sua estória, a heroína She-ra foi separada do seu irmão gémeo, He-man, quando ambos eram bebés e levada para um mundo, Etheria, de uma dimensão paralela à dimensão do planeta Eternia. Já adulta, She-ra, alter-ego da Princesa Adora, lidera a Grande Rebelião, um grupo composto quase exclusivamente por guerreiras do sexo feminino. A Grande Rebelião tem a sua casa e refúgio nos idílicos Bosques Sussurrantes - em inglês The Whispering Woods. Entre os poderes de She-ra estão capacidades especiais de empatia e de comunicação com os animais.

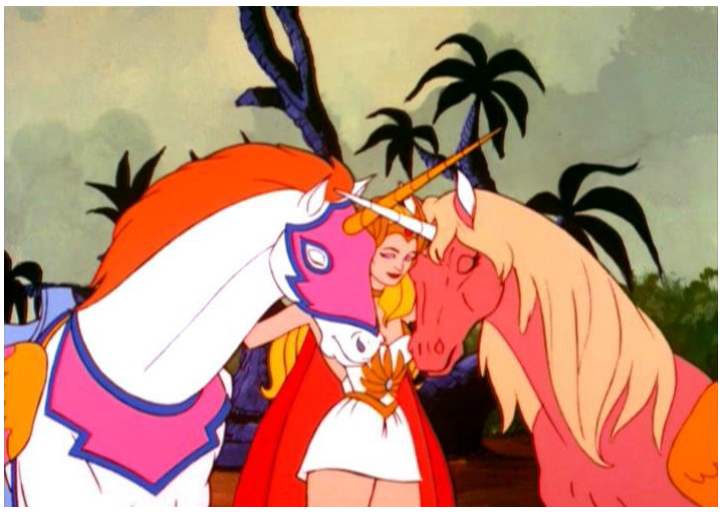

Fig.23.She-ra com os animais (desenhos animados).

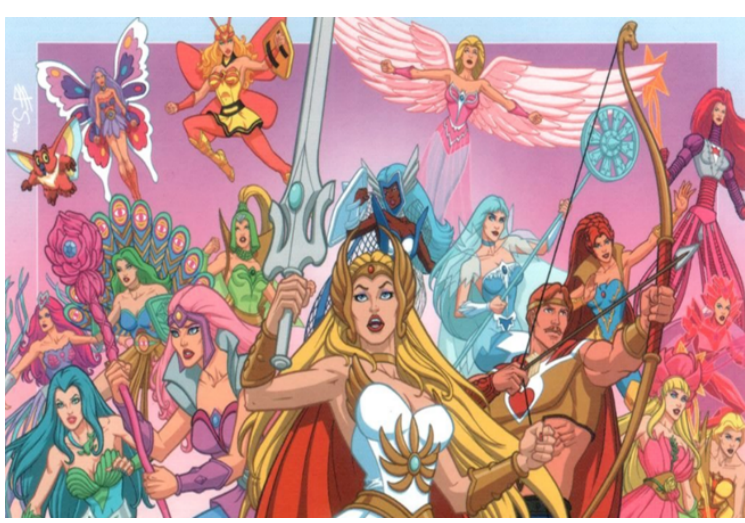

Fig.24. A Grande Rebelião (BD).

She-ra, juntamente com a Grande Rebelião, tenta libertar Etheria do domínio da terrível Horda do Mal, comandada por Hordak. Ao contrário da Grande Rebelião, a Horda do Mal habita a chamada Zona do Medo, um lugar ambientalmente carregado e degradado. A Horda do Mal pauta o seu comportamento pela constante aterrorização e escravização dos povos de Etheria. Nestas estórias é possível, aliás, distinguir quadros e simbologia que lembram a Guerra Fria que ainda se vivia na década de 80, partindo do princípio que se trata de representações na perspetiva norte-americana. Com efeito, o comportamento da Horda do Mal pode ser associado de forma indireta ao comportamento de regimes totalitários e ditatoriais que persistiram na Europa entre a II Guerra Mundial e o fim da Guerra Fria e que se constituíram como inimigos dos Estados Unidos da América. A simbologia vermelha da Horda do Mal e a sua conduta de escravização de povos, levando-os, inclusivamente, a trabalhos forçados em campos dedicados a esse efeito, lembram a simbologia e as práticas perpetradas por regimes como os soviéticos e os nazis. A propriedade do Mal é, neste sentido, atribuída ao "outro" na narrativa das estórias de She-ra. 


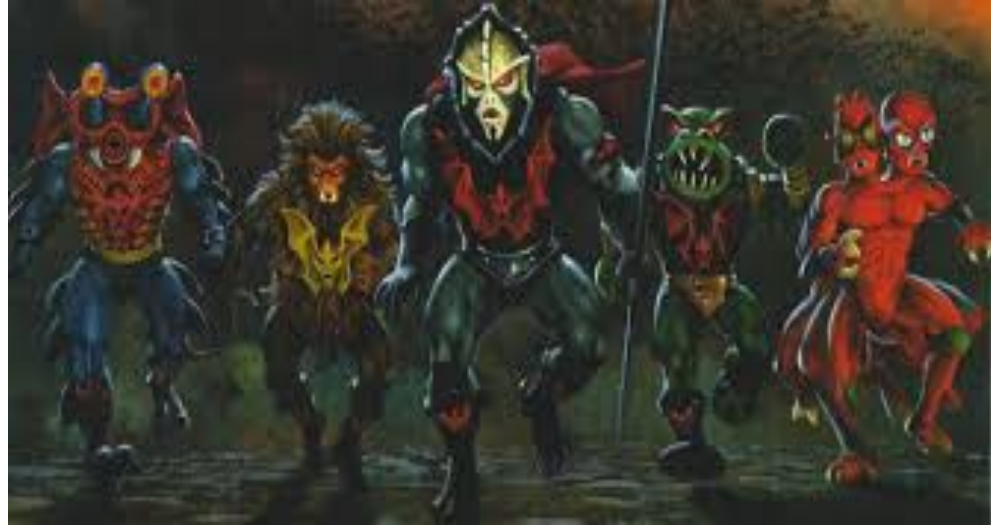

Fig.25. A Horda do Mal (da esq./dir.): Mantenna, Grizzlor, Hordak, Leech e Modulok.

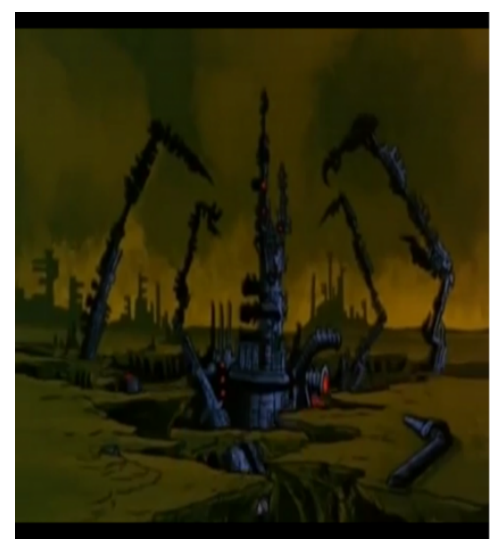

Fig.26. A Zona do Medo (des. ani.).

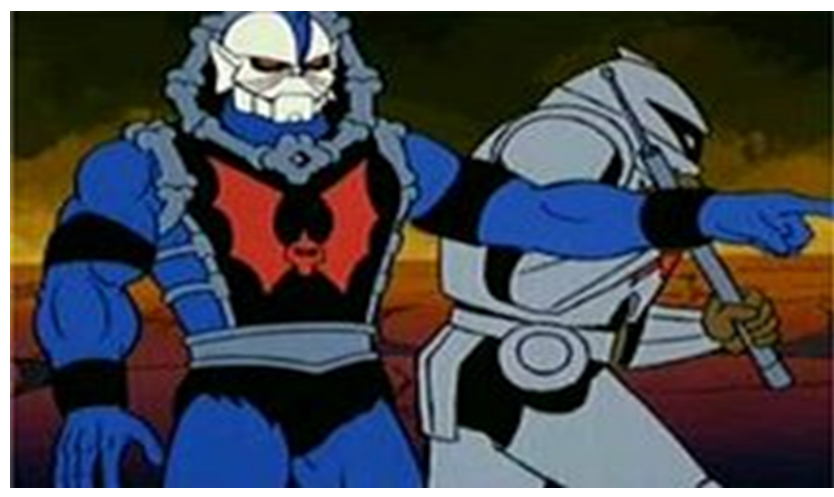

Fig.27.Hordak ordenando um dos seus soldados (des. ani.).

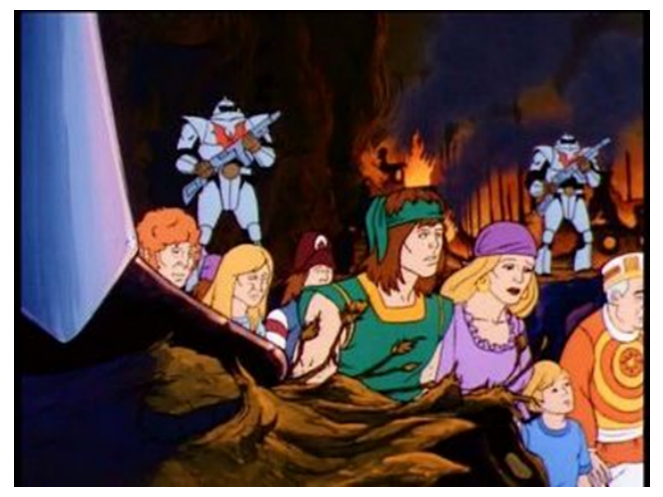

Fig.28.Povo escravizado pela Horda do Mal (des. ani.).

Por outro lado, tal como no universo MOTU, She-ra: Princess of Power também estendeu o franchising aos brinquedos com a linha action figures da Mattel e à banda desenhada. Tanto o universo de He-man como o universo de She-ra foram, ao longo dos anos, representados na BD de várias formas, como comics, mini-comics, revistas e até livros, por várias empresas, incluindo as gigantes DC Comics e Marvel Comics (Selley \& Selley, 2015).

\section{The New Adventures of He-man}

Após alguns anos de interregno das representações do universo MOTU, numa parceria entre a Jetlag Productions e a Mattel, tem início, em 1990, a transmissão das The New Adventures of He-man, em português As Novas Aventuras de He-man. Nesta nova série, He-man incorpora um novo visual e deixa o seu planeta natal, Eternia, para viajar para o futuro até ao planeta Primus. Em Primus junta-se ao grupo dos Guardiões Galácticos para defender o planeta, habitado pelos últimos elementos da espécie humana, da invasão dos terríveis mutantes. Os mutantes têm como aliado Skeletor, o arqui-inimigo de He-man que perseguiu o herói para este novo mundo. Primus é um planeta onde os últimos humanos vivem num ambiente altamente avançado do ponto de vista tecnológico tendo ao seu serviço robôs muito inteligentes. Veja-se que num cenário de anos 90 , onde cada mais se começou a ouvir falar de avanços em áreas científicas como as biotecnologias, a engenharia genética, a clonagem ou a inteligência artificial, o herói principal do universo MOTU, He-man, é colocado num mundo futurístico, habitado pelos últimos seres 
humanos, que ajuda a defender da invasão de seres mutantes. Está aqui implícita a ideia de ameaça à espécie humana, tal como a conhecemos hoje, vinda da parte das novas áreas de ponta da investigação científica, como é o caso da engenharia genética e da inteligência artificial.

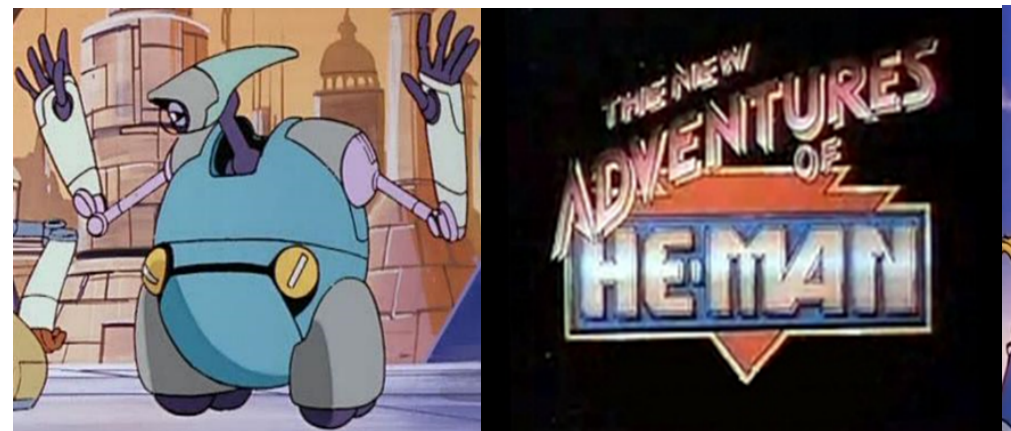

Fig.29. Um robô de Primus.

Fig.30. Logotipo da série televisiva.

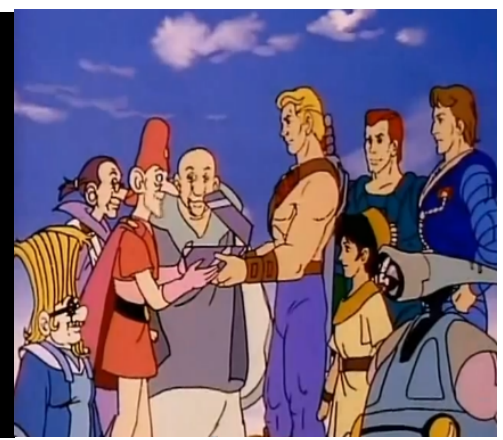

Fig.31.He-man com habitantes de Primus.

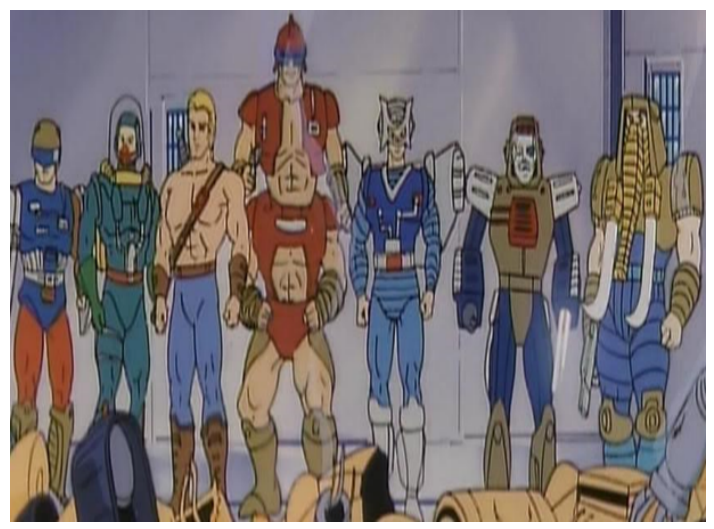

Fig.32. He-man (3o à esquerda) com os Guardiões Galácticos.

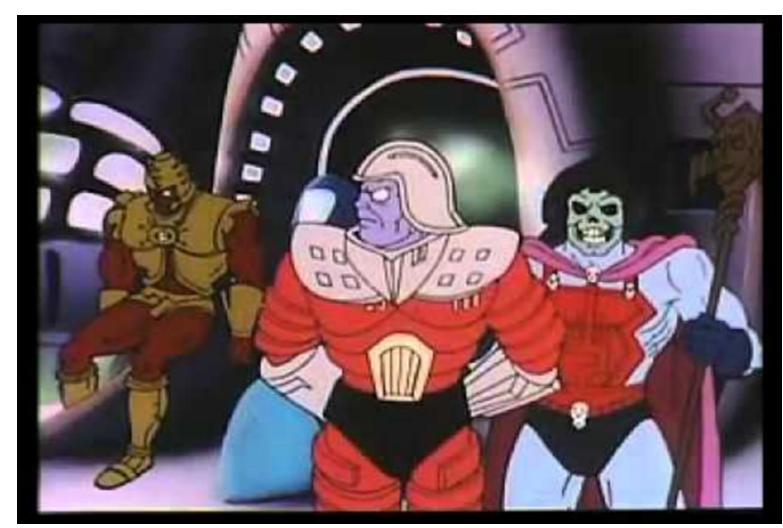

Fig.33.Skeletor (à dir.) com os mutantes Quakke e Flogg (esq/cen.).

Como pode ser verificado na respetiva legendagem, os elementos referidos desta série televisiva são exemplificados nas figuras acima. No entanto, tal como as séries televisivas dos anos 80, esta nova série de He-man também foi acompanhada com um franchising de produtos em outras áreas como a banda desenhada e as actions figures. Uma característica que está precisamente na génese e na natureza do universo MOTU, ao longo das suas várias representações em diferentes décadas, é a lógica de franchising expandido a diferentes áreas de negócio (Selley \& Selley, 2015). Esta caraterística manifesta-se, assim, na primazia que é dada aos aspetos económicos e de rentabilidade dos produtos criados. É algo que não está dissociado dos aspetos ideológicos incluídos nas estórias de He-man, como é o caso do padrão de corpo que obedece aos preceitos estéticos neoliberais, nomeadamente a eficiência e a otimização corporal que integra padrões bem definidos e/ou padrões futurísticos. 

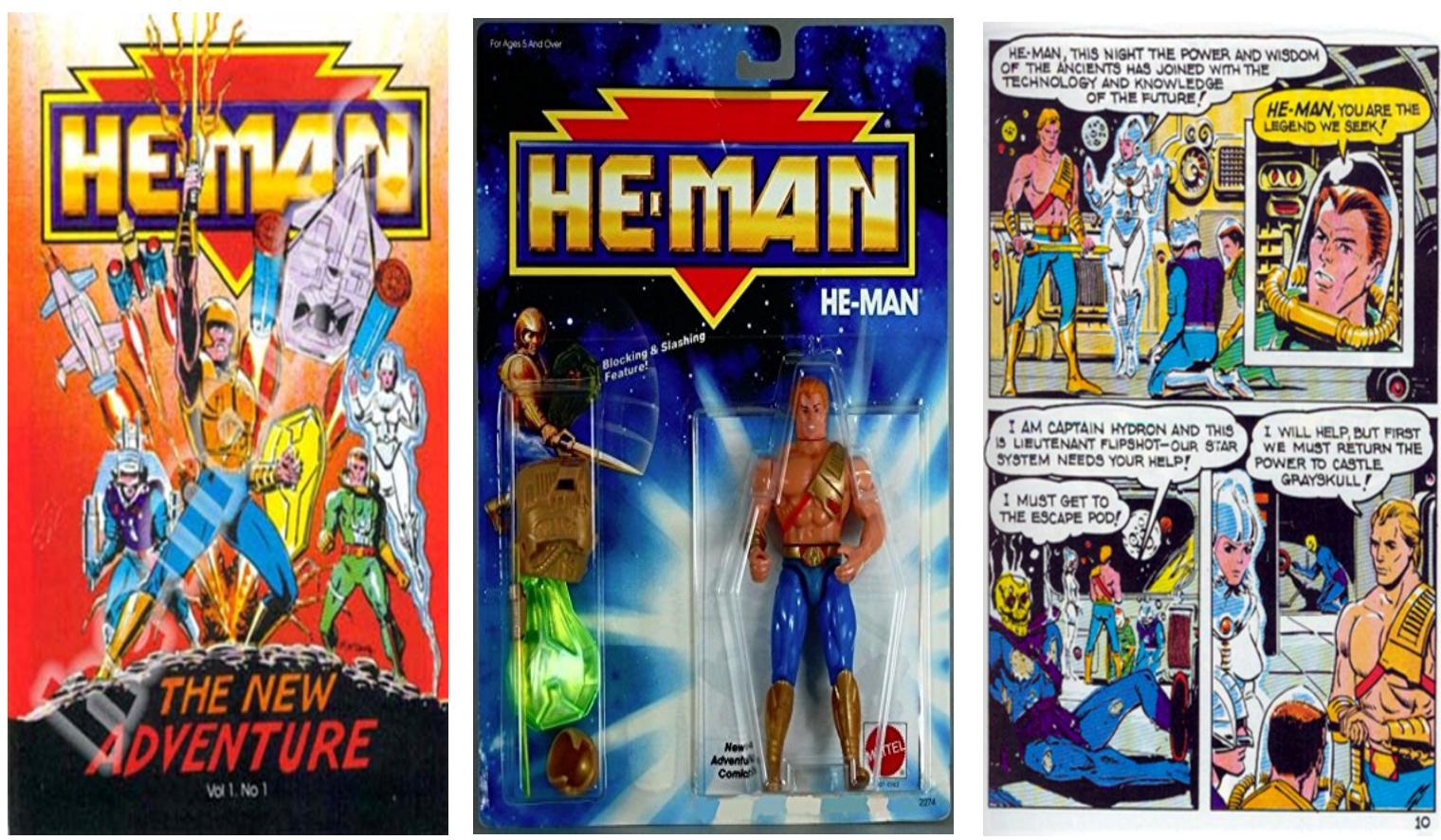

Fig.34 e fig.35.A nova série de aventuras de He-man em banda desenhada.

Fig.36. Nova action figure He-man.

\section{MOTU e She-ra no século XXI}

Há que referir que tanto as personagens do He-man como da She-ra têm tido novas representações na cultura popular do século XXI. Entre 2002 e 2004, os estúdios de animação Mike Young Productions lançaram para a televisão He-Man and the Masters of the Universe como um reboot das séries originais dos anos 80 (Selley \& Selley, 2015). Nesta altura, He-man volta a ser colocado no seu planeta natal, Eternia, com os seus antigos amigos na luta contra Skeletor e os seus comparsas. No entanto, nesta série, o universo ficional sofre uma expansão e um desenvolvimento, incluindo na caraterização das personagens, que não haviam sido realizados antes. Concretamente, é desenvolvida a estória do planeta Eternia e a estória da família de He-man, antes do próprio personagem ter nascido. Fica claro que o planeta Eternia é um mundo com um historial de lutas de poder entre diferentes povos e entre diferentes grupos de seres, num ambiente repleto de misticismo e de poderes mágicos que se fundem com os elementos tecnológicos. $\mathrm{O}$ Príncipe Adam, ao receber o poder do Castelo de Grayskull, encarna He-man, o mais recente representante de uma linha de guardiões do Castelo e de Eternia contra as forças do Mal. Skeletor é revelado como sendo Keldor, tio do Príncipe Adam, que ficou desfigurado numa luta onde interveio o Rei Randor, pai de Adam/He-man e irmão do próprio Keldor. Desde então, Skeletor ficou obstinado com o desejo de vingança e de conquista do poder de Eternia. Há, nesta medida, uma intricada trama familiar que, nas representações mais recentes, surge desenvolvida no universo MOTU. No entanto, no plano comercial, com este reboot volta a ocorrer a lógica de alargamento do franchising a outras áreas de negócio como a banda desenhada e as actions figures.

Em 2012, após uma revisão da coleção action figures realizada alguns anos antes, a DC comics lança na banda desenhada uma nova saga dos Masters of Universe (Selley \& Selley, 2015). Embora o cenário continue a ser o planeta Eternia e essencialmente o mesmo grupo de personagens principais das séries originais, nesta linha de estória existe desde muito cedo uma fusão entre os universos ficionais de He-man e de She-ra. Também se verifica que se trata de recriações com um nível de maturidade e de violência muito 
superiores àquilo que era comum nas séries dos anos 80 e 90. Isto acontece porque, ao longo do tempo, os Masters of the Universe não se caraterizaram tanto pela angariação de um número elevado de fãs nas novas gerações mas sim pela fidelização da grande base de fãs conseguida nos anos 80 . Estes fãs, à medida que foram crescendo do ponto de vista etário, foram tendo necessidade de ver e de ler nas estórias um realismo que tenha em conta a natureza e os elementos das mesmas, o que em muitos casos implica um nível de violência superior. Ou não estivéssemos a falar, por exemplo, de uma Horda do Mal que viaja de planeta em planeta escravizando povos mas que, ao mesmo tempo, encontra impedimento aos seus intentos num grupo de super-heróis que a combate e que lhe dá guerra, no sentido literal do termo. Um leitor de idade adulta compreende que este tipo de cenários não encontra resolução em lutas de caráter infantil que muitas vezes preenchiam as estórias do anos 80 , uma vez que estas estórias eram dirigidas a um público infantil. Para fidelizar os leitores ou os fãs adultos, a saga de He-man necessitou, nesta altura, de apresentar resoluções realistas de lutas que, por natureza, são altamente violentas. Inclusivamente, a DC comics tem vindo a realizar crossovers entre os Masters of the Universe e outros universos ficionais como os ThunderCats e a Liga da Justiça, que inclui personagens como o Super-Homem, o Batman, a Mulher-Maravilha e o Flash. Este tipo de crossovers abre novas possibilidades na formulação dos imaginários populares ao cruzar universos e personagens que, à partida, eram de natureza distinta.

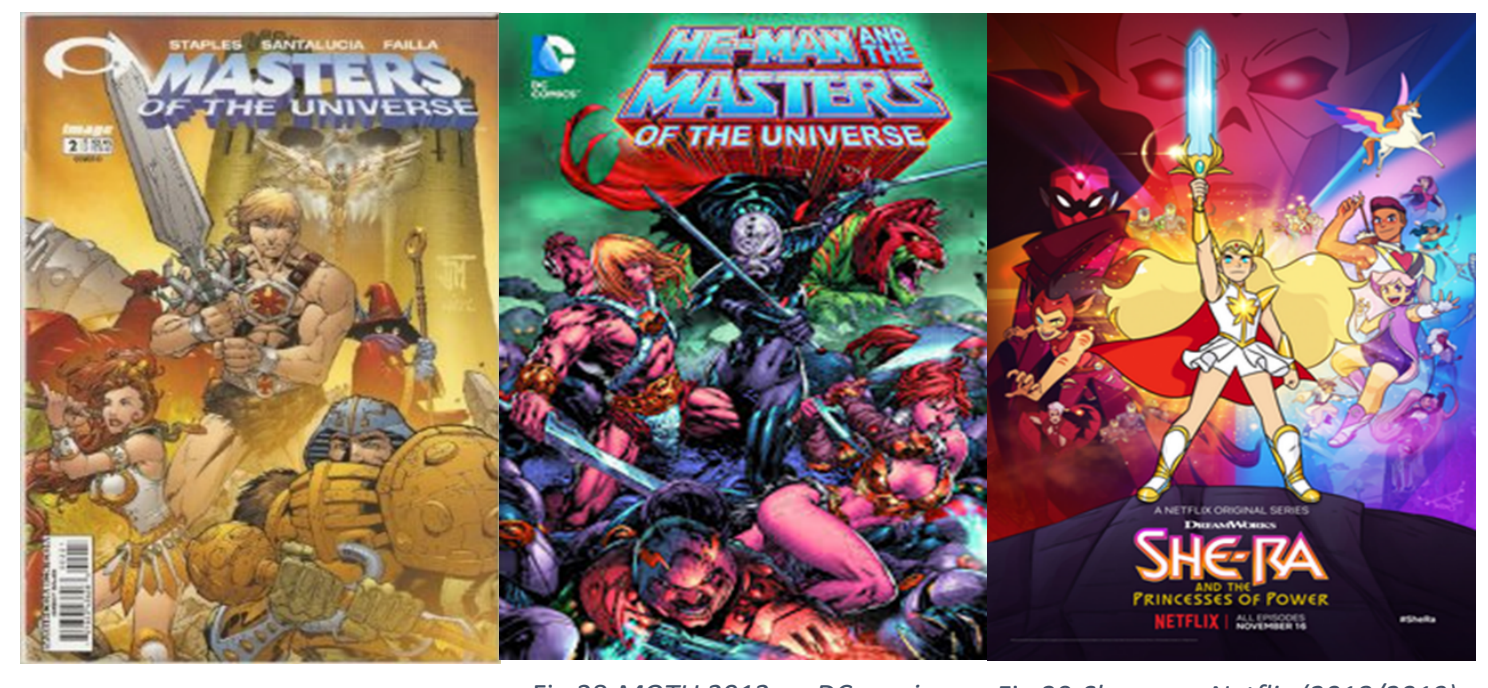

Fig.39.She-ra na Netflix (2018/2019).

Finalmente, em novembro de 2018, estreou na Netflix uma nova série de animação da She-ra, intitulada She-Ra and the Princesses of Power, em português She-ra e as Princesas do Poder, produzida pela jovem Noelle Stevenson. Neste caso trata-se de uma série de animação dirigida a um público eminentemente infantil mas que tem vindo a receber boas críticas e à qual a Netflix deu continuidade no ano de 2019, inspirando-se nos elementos base das estórias da She-ra dos anos 80, incluindo na desconstrução de visões de género e de sexualidade. Nesta nova série voltamos a ver um grupo de mulheres heroínas em posições de liderança e de emancipação, assumindo comportamentos, no plano relacional, que estão de acordo com uma agenda ideológica feminista. 


\section{Conclusão}

Podemos concluir sobre as representações dos universos ficcionais He-man e She-ra que, ao longo dos anos e das décadas, estes universos integraram elementos culturais e ideológicos diversos e até oriundos de correntes contraditórias. Às visões tecnocientíficas, politizadas e militarizadas das personagens, das estórias e dos cenários, próprias da tecnocultura dos anos 80 do século passado, juntaram-se elementos da mesma década que denotavam preocupação com imagens de emancipação feminina, de preservação dos equilíbrios ecológicos e de debate sobre a natureza humana. Podemos dizer que são universos onde convergem tanto elementos que podem ser considerados de emancipação como elementos que podem ser considerados de reprodução de fenómenos de dominação. Para além disso, a fusão de elementos tradicionais com elementos da modernidade também se pode identificar em personagens de animais, o que revela elementos de tecnoanimalismo. Essa fusão, e até tensão, verificadas entre a tradição e a modernidade pode evidenciar, no universo MOTU, a crise da noção de progresso social e tecnológico que a pós-modernidade encerra. Como Bruno Latour (2009) defende em Jamais fomos modernos, a proliferação dos híbridos na sociedade contemporânea realça o facto de a modernidade nunca se ter concretizado por completo na prática pois o ser humano nunca se desligou de formas de vida não-humanas. Esta hibridação do humano com formas de vida não-humanas coloca em causa a constituição moderna enquanto base programática e ideológica. Nesta medida, as referidas estórias apresentam figuras que diluem as fronteiras entre o humano, o animal e a máquina.

Inclusivamente, a referida miscelânea de elementos é uma caraterística da própria cultura popular, aqui desenvolvida numa lógica de cultura de massas num franchising que se estendeu a várias áreas de negócio como os brinquedos, os desenhos animados, a banda desenhada e o cinema, entre outros. Neste sentido, revelam-se alguns elementos ideológicos que se prendem à estética neoliberal e que se traduzem numa noção de corpo funcional e eficiente. Aliás, o lucro financeiro e o sucesso na crítica que os produtos dos Masters of the Universe foram conseguindo ao longo dos anos revelaram-se decisivos para o seu prolongamento no mercado ou, pelo contrário, para a sua retirada do mesmo. Não foi por acaso que as representações desenvolvidas no século XXI recuperaram, tanto para o He-man como para a She-ra, as fórmulas de sucesso dos anos 80 do século XX, acrescentando, no entanto, maior realismo e maturidade às estórias de acordo com as necessidades de um público fidelizado desde o início das sagas. Este facto deve, ainda assim, realçar o cuidado que deverá existir na análise filosófica e ideológica de conteúdos que começaram por ser dirigidos a crianças e que foram evoluindo, nem sempre de uma forma muito coerente, para obedecer a ditames comerciais. De qualquer modo, há que registar que um olhar mais atento e sistematizado sobre as diferentes recriações destes universos ficcionais pode ser interessante no âmbito do estudo académico para revelar como diferentes formas de representação do pós-humano se foram cruzando ao longo de diferentes décadas em produtos comerciais de âmbito popular e massificado.

Hoje desenvolvem-se os planos para a realização de um novo filme dos Masters of the Universe. Este filme, para não cair no logro comercial e crítico que o seu antecessor teve quando foi lançado em 1987, terá de corresponder à dimensão ambiciosa do universo ficcional MOTU tirando, ao mesmo tempo, os devidos proveitos financeiros. Torna-se, portanto, necessário encontrar, entre outras coisas, um argumento para uma estória que faça corresponder a um investimento elevado o devido retorno, desde logo, na bilheteira. No entanto, os Masters of the Universe são claramente um campo com grande potencial de expansão (Selley \& Selley, 2015), não só no que diz respeito ao desenho de produtos comerciais, como ao desenvolvimento das estórias e de um universo ficcional que 
apresenta muitos elementos interessantes, nomeadamente respeitantes à exploração de futuras representações do pós-humano.

\section{REFERÊNCIAS}

Darwin, C. (2009). A origem do homem e a seleção sexual. Lisboa: Relógio D’Água.

Foucault, M. (1993). História da sexualidade (vol. I). Rio de Janeiro: Edições Graal.

Haraway, D.J. (1995). Simians, cyborgs, and women: The reinvention of nature (2th ed.). London:Free Association Books.

Latour, B. (2009). Jamais fomos modernos (2 ed.). São Paulo: Editora 34.

Maia, J. (2018). Globalização, escola e ensino intercultural da História e da Geografia. Saarbrücken: Novas Edições Acadêmicas.

Maia, J. J. M. (2017). Transumanismo e pós-humanismo: Descodificação política de uma problemática contemporânea (Tese de doutoramento não publicada). Coimbra: Instituto de Investigação Interdisciplinar da Universidade de Coimbra.

Miranda, J. B. (2002). Teoria da Cultura. Lisboa: Século XXI.

Selley, S. \& Selley, T. (2015). The Art of He-Man and the Masters of the Universe. Milwaukie: Dark Horse Books.

Wiki Grayskull. (2019). MOTU and She-ra images [imagens]. Consultado em https://he-man.fandom.com/wiki/Masters of the Universe 